\title{
Innovation of New Knowledge in Sustainable Tourism through Social Innovation
}

\author{
Judita Peterlin, Vlado Dimovski \\ Faculty of Economics University of Ljubljana, Slovenia
}

\section{Abstract}

The goal of our paper is to present the knowledge management process of social innovation endeavour undertaken in the field of sustainable tourism of the capital of Slovenia. We present all phases of social innovation and focus on the findings of the second phase. We use the methodology of social innovation that is composed of structured open-ended questionnaires. Questionnaires took 30-40 minutes to be filled out. The answers were transcribed and analysed with NVivo 10 software. We conclude that social innovation is a beneficial methodology that provides the inclusion of key stakeholders in sustainable tourism. That is, local community has an opportunity to be heard, empowered and engaged in sustainable tourism initiatives and activities that not only enrich the spectre and essence of sustainable tourism offer but also preserve, cultivate and nurture the human potentials of the locals by including and valuing their ideas and creative solutions to social and environmental challenges.

Keywords: social innovation, sustainable tourism, stakeholders, participative management

JEL classification: M10, M14

Acknowledgments: We wish to thank European Social Fund.

\section{Introduction}

Nature of the problem in sustainable tourism is that it sometimes neglects to take into consideration all four main principles of sustainable tourism; therefore in this paper we focus on highlighting the need to involve the local community at the beginning of sustainable tourism offer design. Taatila et al. (2006) states that research on innovation has widened to include consideration of the impact of social networks on the innovation. Current state of knowledge in sustainable tourism and social innovation is at its beginning which means that there are many possibilities for researching them. Our motive for presented research is to answer our research goal and present the knowledge management process of social innovation endeavour undertaken in the field of sustainable tourism of the capital of Slovenia. Moscardo (2008, p. 4) highlights the importance of better knowledge management systems to support innovation in tourism and claims that one option to develop new ways of thinking and innovation in tourism is to argue that there is no such thing as sustainable tourism. If we begin with the assumption that tourism cannot be sustainable in its own right but may contribute to the sustainable development of some regions under some circumstances, then a number of new approaches to tourism development emerge, such as links between tourism and other economic activities and development options (Moscardo, 2008, p. 4). Our research is based on an identified research gap in the existing literature that sustainable tourism is lacking the active involvement of local community in its efforts (Hardy et al., 2002), therefore we have based our research on finding out through social innovation methodology 
what kind of sustainable tourism does local community in Ljubljana imagine and how the preferred business model could be sustained by involving key stakeholders in the local community. Potential usefulness of proposed theoretical basis is an active implementation of the identified sustainable business models in Ljubljana through collaboration with the local authorities and local company Kaaita, d.o.o. Our purpose is to present the scope of social innovation methodology and focus on the findings of the second phase in sustainable tourism initiative at the local Slovenian level.

Structuration theory, institutional theory and the domain of social innovation focus on the interrelationship between agents and social systems, therefore these theories are particularly applicable to the nature of social innovation process, especially since the quality of theoretical work in this field of social innovation has been identified as underdeveloped. Institutional theory defines social innovation as a result of the exchanges of knowledge and resources by actors mobilized through legitimization activities and structuration theory states that social innovation is socially constructed as individuals collectively engage in purposeful actions and reflexively monitor the outcome of their actions (Cajaiba-Santana, 2014, p. 49). Social innovation, which is aimed at developing new ideas and solutions in response to social needs, is aimed at building long-term relationships with stakeholders in order to create networks from which design opportunities can emerge (Hillgren et al., 2011).

\section{Sustainable tourism}

European council presented in 2001 the strategy of sustainable development in EU. Strategy was based on the principle that all economic, social and environmental aspects need to be taken into consideration when decisions are being made. It was realized that EU has many politics that need to be aligned and the focus needs to be cleaner, safer and healthy environment for stakeholders. Sustainable development is defined as development that meets the needs of the present generation while not endangering the chances of future generations to have a dignified existence (Brundtland Commission, 1987). Sustainable development is a change management process in which resource usage, technological progress and institutional changes are integrated and rise present and future generation's potential for meeting community needs.

Tourism is one of the largest global industries and has become one of the fastest growing business sectors. Vital for the sustainability of the tourism is the awareness of environmental protection, its resources, biodiversity and respect towards social and cultural authenticity of local communities in order for tourism to provide long-term economic success. "Sustainable tourism is a tourism that takes into consideration present and future economic, social and ecological impact and satisfies the needs of the visitors, business, environment and local community" (UNEP, 2005 in Mihalič, 2006).

Sustainable tourism is based on the following principles:1) environmental (protection of plants, animals, decrease pollution that touristic companies and tourist cause); 2) social-cultural (raising cultural and historical heritage of local communities and preserving the quality of life in the countryside); 3) economic(providing competitive advantage and constant development of touristic destinations and companies) and4) climate (decrease impact of tourism on climate).Sustainable tourism lies on economic success and understanding of natural, social-cultural environment in order to be long-term competitive. Sustainable tourism has the following values: 1) focus on local capabilities and uninvasive usage of natural resources through collaboration of different stakeholders; 2) improving quality of life 
in the countryside because natural resources are mainly there; sustaining living conditions in the countryside; 3 ) protection of the environment with the collaboration of the local communities and raising awareness of key stakeholders; 4)environmental education of youth and adults.

\section{Methodology}

Structured qualitative methodology of social innovation is used in order to identify the needs of the local community in respect to the development of sustainable tourism in the capital of Ljubljana. Mumford (2002) argues that due to methodological reasons social innovation is difficult to research, as social innovations are relatively rare. Social innovations moreover, are typically diffuse involving interactions among multiple parties over rather long periods-which makes traditional experimentation difficult. Pol and Ville (2009, p. 884) stress that to understand the sources of innovation we need to understand the milieu in which social innovation takes place. There must be an appropriate environment conducive to the creation of new ideas and a context in which a new idea is socially innovative.

"Social innovation refers to new ideas that solve existing social, cultural, economic and environmental challenges in a socially and environmentally responsible way. A true social innovation changes the existing system - permanently changing the perception, behaviour and structures that previously enabled the existence of these challenges"'"(The Centre for Social Innovation, 2015)". It means, therefore, the idea which has a beneficial impact on the public good. Mulgan (in Mesojedec et al., 2012 , p. 37) defines social innovation as: "The activities and services intended to meet social needs, and are implemented in organizations whose primary purposes are social." When we are social innovators, it means that we create innovative solutions for a specific societal or environmental challenge, where our solutions are more effective and durable than existing ones; their impact is not just for individuals, but primarily society and natural environment as a whole. This is a comprehensive and complex process of development of new products and services that bring lasting and effective change in usual practices in the natural-social system. In the EU there is not a single definition of social innovation, mostly it is defined as the process of developing imaginative solutions to social business environment, with a view to finding solutions to social and environmental needs for which the market and the public sector do not have complete answers.

Murray, Caulier-Grice and Mulgan (in Mesojedec et al. 2012, p. 39) have identified six steps in the implementation of social innovation, namely: 1) stimulus inspiration and diagnosis; 2) proposals and ideas; 3) prototypes and pilot experiments; 4) sustaining; 5) dissemination; and 6) a change in the system. In this paper we present the results of the first two phases of the method of social innovation, where we gathered proposals, ideas and diagnosis from the local community together with the collaboration of the mayor of the Municipality of Ljubljana and reputable managers. Based on the Moulaert et al. (2007) comparison of neo-liberal and social innovation discourses about urban socio-economic change, including associated policies and key agencies, we conducted a focus group with key actors in the field of sustainable tourism of the capital. 
Figure 1

Phases of social innovation

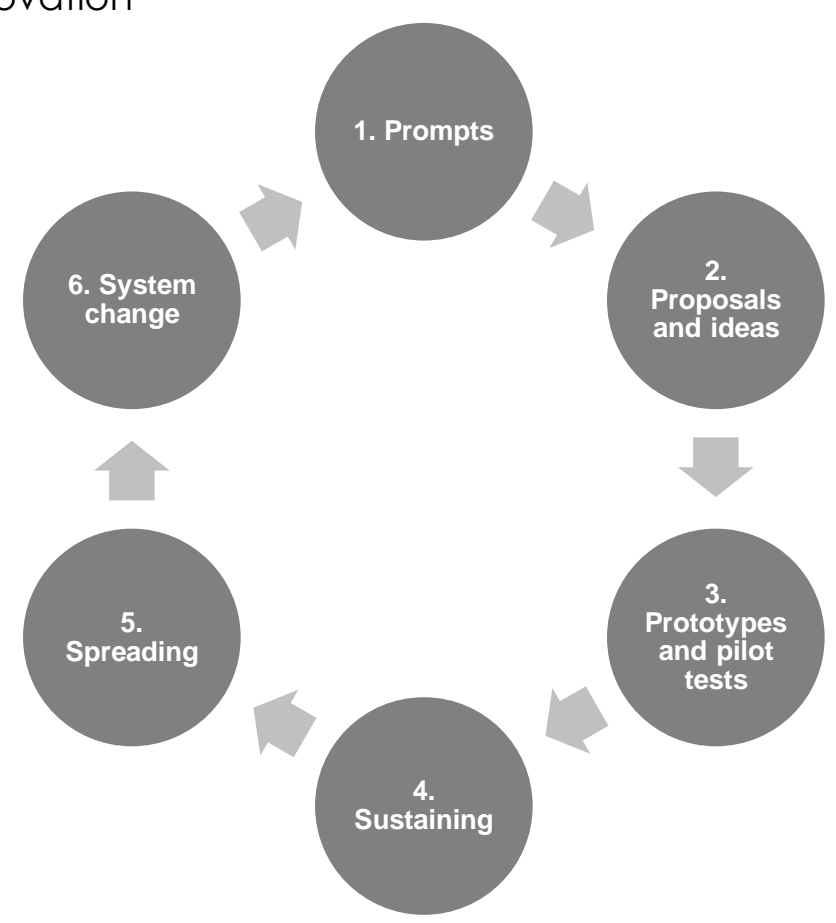

Source: Murray, Caulier-Grice \&Mulgan v Mesojedec et al. 2012, p. 39

Data was gathered during the project financed by European Social Fund that took place from 1st March - 1st June 2015. In July 2015 the models were presented to the public. Students were funded by European Social Fund to conduct social innovation questionnaires that would improve the satisfaction of Ljubljana's local community with the surroundings and engagement of local community in helping offer integrated sustainable tourism options.

In the first research phase, professors have chosen the methodology, adjusted the questionnaire of social innovation to meet the needs of sustainable tourism and conducted workshops for students how to carry out the questionnaires. The questionnaire has 7 main structured questions that last 30-40 minutes, depending on the quantity of answers of the recipient. Questions range from the identification of the need a participant wants to satisfy in Ljubljana, then solutions are discussed and at the end one solution are chosen by the participant as most valuable and ways for its implementation are made more concrete.

Based on 326 questionnaires the students identified together with the working mentor from business environment three models that were rated as the most suitable. We need to acknowledge that gathered data did not present the models in its final form and that three models are a result of social innovation methodology. Based on gathered data, the students used their imagination, skills from three faculties, recommendations from business manager and mentors and presented to the interested public on 29th June their work. Feedback was valuable and further improvements and possibilities for implementation are discussed with Tourism office of Ljubljana. 


\section{Results}

Based on the 326 questionnaires gathered during the project funded by Social European Fund we have compiled social innovation suggestions that have been wildly present in the findings and further analysed in NVivo software for qualitative research findings. The emerged findings for social innovation in the wider perspective were: 1) renovation of the main train station in Ljubljana; 2) relaxation park with the wall of impressions; 3) traditional Slovene cuisine of Ljubljana; 4) Barje - natural park in the suburbs of Ljubljana; and 5) Ljubljana's entrance door.

Key identified needs in managing sustainable tourism of Ljubljana for participants were identified as:

- "feeling of home, safety, feel the vibe of the capital"

- "order, liveliness, relaxation, information"

- "more attractive presentation of Ljubljana for young tourists and customized research of Ljubljana with wider span of activities"

- "more storytelling and enabling tourists to feel the city vibe and way of living in Ljubljana"

Participants also expressed the need for engaged and entertaining alternatives in sustainable tourism offers. The findings are supported with proof citations from the questionnaire participants and local community involved, including experts in the field of sustainable tourism, such as:

- "organize a biking tour to the wetland of Ljubljana's marshes"

- "houses in the trees for learning, playing, shops in the urban parks"

- "getting to know the eating habits of locals and ingredients in their food"

Based on the collaboration with the business environment three models were narrowed down and made concrete in collaboration with the Faculty of Architecture University of Ljubljana and Faculty of Natural Sciences and Engineering University of Ljubljana: 1) Dragon's path; 2) Ljubljana's cuisine; 3) renovation of Ljubljana's main train station.

Results of presented social innovation are three models of sustainable tourism, that were also provided in 3D form for interested public. Students have identified business opportunities in connecting different parties in the local community.

Renovation of the main train station enables a positive impression of Ljubljana. When presenting publicly the results, it was said that flower beds with white roses (as flower of Ljubljana) would beautify the main station. Students of art would be able to develop and present their talents by drawing the walls of the main train station.

Authentic tastes model was rated by the owner of one of the best restaurants in Ljubljana, Janez Bratovž, as interesting and the students prepared a poster for further presentation of the results. This model aims to present poorly known traditional dishes by using wooden spoons, forks and knifes as these were used in Slovene heritage and are claimed to preserve authentic taste of food.

Dragon path aims to show interesting spots in Ljubljana where city's symbol Dragon is presented but not in the centre of attention, such as on bridges, paintings, walls. Tourists (and also locals) will be invited on an experiential trail where they will sow with a thread their own trail chosen that is composing the note-book that each participant of the trail will receive at the beginning of the trail. The note-book will be made out of the recycled paper. Tourism office in Ljubljana demonstrated interest for its implementation and students are further developing the model. 


\section{Discussion}

Capacity for technological and social innovation is needed for sustainable functioning of sustainable tourism. Local research and development partnerships, implementation research, and individual leadership are needed to achieve this goal (Gardner et al., 2007). With the aim of identifying models for sustainable tourism we have designed three propositions based on the needs of the local community and business setting.

First model Dragon's path - Let's find the dragon proposes a creative notebook where visitors would gather stamps of dragon (city's symbol) and make their own path around Ljubljana in collaboration with the Ljubljana restaurants. The aim is to make the visit of Ljubljana entertaining and educational by engaging visitors in the individualized city tour.

Second model Ljubljana's cuisine focuses on authentic tastes of Ljubljana's cuisine by proposing Slovene heritage - wooden forks, knives and spoons in getting to know traditional dishes of Slovene regions. Wood is a sustainable material and also preserves authenticity of the dish taste.

Third model Renovation of Ljubljana's main train station proposes the engagement of local community - especially younger generations in cleaning and revitalising train station with new paintings and artefacts as the main train station is one of the main entrances and first contacts for a lot of tourists with Ljubljana.

Identified and designing models of sustainable tourism are derived from solving existing challenges the local community has identified in their environment. Social challenges are connected to environmental challenges and social innovation develops through a systematic approach possible solutions to complex challenges. Based on social innovation database we have developed three models of sustainable tourism that rely on the involvement of local community.

\section{Conclusion}

In our paper we have conceptualized social innovation in the field of sustainable tourism and based on the gathered data provided several social innovation proposals that were analysed in collaboration with sustainable company Kaaitaand three of them were carried out through social innovation process. Limitations of the study are the focus on one city, further research on other cities around the globe is recommended to provide the development of social innovation in urban environment. Limitation of the study stems from resource limitation as we only present three possible models, whereas the data gathered enables many more future models development. We conclude that interdisciplinary focus of the project group was vital for knowledge management of social innovation as students gained additional knowledge and connected insights from different study fields with valuable recommendations from business mentor who was focused on creating added value for business and social community.

\section{References}

1. Brundtland Commission (1987), "Our Common Futures", available at: http://www.umanotera.org/index.php? node=5 (accessed May 30th 2015)

2. Cajaiba-Santana, G. (2014), "Social innovation: Moving the field forward. A conceptual framework", Technological Forecasting \& Social Change, Vol. 82, pp. 42-51.

3. Gardner, C.A., Acharya, T., Yach, D. (2007), "Innovation: A Unifying New Paradigm for Global Health", Health Affairs, Vol. 26 No. 4, pp. 1052-1061. 
4. Hardy, A., Beeton, R.J.S., Pearson, L. (2002), "Sustainable tourism: An overview of the concept and its position in relation to conceptualisations of tourism", Journal of sustainable tourism, Vol. 10 No. 6, pp. 475-496.

5. Hillgren, P.-A., Seravalli, A., Emilson, A. (2011), "Prototyping and infrastructuring in design for social innovation", CoDesign, Vol. 7 No. 3-4, pp. 169-183.

6. Mesojedec, T., Šporar, P., Strojan, K., Valentinčič, T., Bačar, F., Sakovič, G., Strojan, T. (2012). Socialnopodjetništvo, Ljubljana, Salve.

7. Mihalič, T. (2006), "Trajnostni turizem", Ljubljana, Ekonomska fakulteta.

8. Moscardo, G. (2008), "Sustainable tourism innovation: Challenging basic assumptions", Tourism and Hospitality Research, Vol. 8 No. 1, pp. 4-13.

9. Moulaert, F., Martinelli, F., Gonzalez, S., Swyngedouw, E. (2007), "Introduction: Social innovation and governance in European cities: Urban development between path dependency and radical innovation", European urban and regional Studies, Vol. 14 No. 3, pp. 195-209.

10. Mumford, M.D. (2002), "Social Innovation: Ten cases From Benjamin Franklin", Creativity Research Journal, Vol. 14 No. 2, 253-266.

11. Pol, E., Ville, S. (2009), "Social innovation: Buzz word or enduring term?", The Journal of Socio-Economics, Vol. 38 No. 6, pp. 878-885.

12. The Centre for Social Innovation (2015), "Social Innovation", available at :http://socialinnovation.ca/about/social-innovation (accessed May 30th 2015)

13. Taatila, V.P, Suomala, J., Siltala, R., Keskinen, S. (2006), "Framework to study the social innovation networks", European Journal of Innovation Management, Vol. 9 No. 3, pp. 312-326.

\section{About the authors}

Judita Peterlin, PhD is a research and teaching assistant at the Faculty of Economics, University of Ljubljana. She graduated from the Faculty of Social Sciences and Faculty of Economics University of Ljubljana. In the study year 2014/15 she is a teaching assistant at the following courses: Foundations of management and organization, Management - English Track, Knowledge management, and Advanced management. Her main research interests are: social innovation, leadership development, sustainability. Author can be contacted at judita.peterlin@ef.uni-lj.si

Vlado Dimovski, PhD, is a full professor of management and organizational theory at the University of Ljubljana, Faculty of Economics in Slovenia. He received his B.A. degree in Economics at the University of Ljubljana, the B.A. degree in Philosophy at the University of Ljubljana, the M.A. degree in Economics at University of Ljubljana, and the Ph.D. degree in Management and Finance at Cleveland State University. His primary areas of expertise are organizational learning, management, organizational behaviour and leadership. He conducts research on knowledge management and organizational learning process and regularly provides consulting about organizational learning for business entities. Author can be contacted at vlado.dimovski@ef.uni-lj.si 